18. Perez MV, Wang PJ, Larson JC et al (2013) Risk factors for atrial fibrillation and their population burden in postmenopausal women: the Women's Health Initiative Observational Study. Heart 99:1173-1178

19. Asanin M, Stankovic S, Mrdovic I et al (2012) B-type natriuretic peptide predicts new-onset atrial fibrillation in patients with ST-segment elevation myocardial infarction treated by primary percutaneous coronary intervention. Peptides 35:74-77

20. Hwang HJ, Ha JW, Joung B et al (2011) Relation of inflammation and left atrial remodeling in atrial fibrillation occurring in early phase of acute myocardial infarction. Int J Cardiol 146:28-31

21. Aronson D, Boulos M, Suleiman A et al (2007) Relation of C-reactive protein and new-onset atrial fibrillation in patients with acute myocardial infarction. Am J Cardiol 100:753-757

22. Daniels LB, Maisel AS (2007) Natriuretic peptides. JAm Coll Cardiol 50:2357-2368

23. St John Sutton M (2008) Quest for diastolic prognostic indicators of clinical outcome after acute myocardial infarction. Circulation 117:2570-2572

24. Kirtane AJ, Bui A, Murphy SA et al (2004) TIMI Study Group. Association of epicardial and tissuelevel reperfusion with left ventricular end-diastolic pressures in ST-elevation myocardial infarction. JThromb Thrombolysis 17:177-184

25. Claeys MJ, Bosmans J, Veenstra L et al (1999) Determinants and prognostic implications of persistent ST-segment elevation after primary angioplasty for acute myocardial infarction: importance of microvascular reperfusion injury on clinical outcome. Circulation 99:1972-1977

26. Van Herck PL, Carlier SG, Claeys MJ et al (2007) Coronary microvascular dysfunction after myocardial infarction: increased coronary zero flow pressure both in the infarcted and in the remote myocardium is mainly related to left ventricular filling pressure. Heart 93:1231-1237

27. Sinno H, Derakhchan K, Libersan D et al (2003) Atrial ischemia promotes atrial fibrillation in dogs. Circulation 107:1930-1936

28. Satoh T, Zipes DP (1996) Unequal atrial stretch in dogs increases dispersion of refractoriness conducive to developing atrial fibrillation. JCardiovasc Electrophysiol 7:833-842

29. Coumel P (1996) Autonomic influences in atrial tachyarrhythmias. J Cardiovasc Electrophysiol 7:999-1007

\title{
Erratum
}

Herz 2018 $\cdot 43: 554$

https://doi.org/10.1007/s00059-017-4604-z

Published online: 20 July 2017

๑) Springer Medizin Verlag GmbH 2017

CrossMark

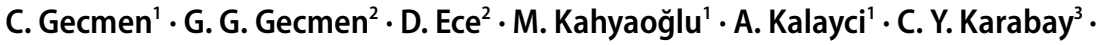

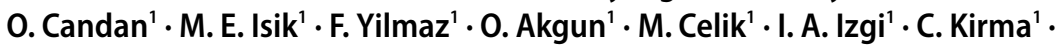
S. Keser ${ }^{2}$

' Department of Cardiology, Kartal Kosuyolu Heart \& Research Hospital, Istanbul, Turkey

${ }^{2}$ Dr. Lutfi Kirdar Education and Research Hospital, Istanbul, Turkey

${ }^{3}$ Dr. Siyami Ersek Chest and Cardiovascular Surgery Hospital, Istanbul, Turkey

\section{Erratum to: Cytopathology of pericardial effusions}

\section{Experience from a tertiary center of cardiology}

\section{Erratum to:}

Herz (2017)

DOI 10.1007/s00059-017-4596-8

In the above mentioned article, the affiliations of four authors were not given correctly. The correct affiliations of all authors are as follows:

C. Gecmen ${ }^{1}$, G.G. Gecmen ${ }^{2}$, D. Ece ${ }^{2}$, M.Kahyaoğlu ${ }^{1}$, A. Kalayci ${ }^{1}$, C.Y.Karabay ${ }^{3}$, O. Candan ${ }^{1}$, M.E. Isik ${ }^{1}$, F. Yilmaz ${ }^{1}$, O. Akgun ${ }^{1}$, M. Celik ${ }^{1}$, I.A. Izgi ${ }^{1}$, C. Kirma ${ }^{1}$, S. Keser ${ }^{2}$

${ }^{1}$ Department of Cardiology, Kartal Kosuyolu Heart \& Research Hospital, Istanbul, Turkey

${ }^{2}$ Dr. Lutfi Kirdar Education and Research Hospital, Istanbul, Turkey

${ }^{3}$ Dr. Siyami Ersek Chest and Cardiovascular Surgery Hospital, Istanbul, Turkey

The authors and publisher apologize for this mistake.

\section{Corresponding address}

\section{Gecmen, MD}

Department of Cardiology, Kartal Kosuyolu Heart \& Research Hospital

34846 Istanbul, Turkey koronerr@hotmail.com 